\title{
Isıl İşlem Şartlarının Küresel Grafitli Dökme Demirlerin Özelliklerine Etkisi
}

\author{
The Effect of Heat Treatment Conditions on the Properties \\ of Ductile Cast Irons \\ Ezgi Sevgi 1*(D), Osman Çulha 2 (D) \\ ${ }^{1}$ Kocaer Çelik San. ve Tic. A.Ş., İzmir, TÜRKIYYE \\ 2 Manisa Celal Bayar Üniversitesi Mühendislik Fakültesi Metalurji ve Malzeme Mühendisliği Bölümü, Manisa, TÜRKIYE \\ Sorumlu Yazar / Corresponding Author*: ezgi.sevgi@kocaersteel.com
}

\section{Öz}

$\mathrm{Bu}$ çalışmada, küresel grafitli dökme demirlere uygulanan ısıl işlem şartlarının mekanik ve metalurjik özelliklere etkisi araştırılmıștır. GGG-40 küresel grafitli dökme demir numunelerin içerdiği alaşım elementleri JMatPro simülasyon yazılımına işlenmiş ve TTT ile CCT diyagramları elde edilmiștir. Küresel grafitli dökme demir numuneler ısıl işlem fırınında $940^{\circ} \mathrm{C}$ sıcaklıkta $38 \mathrm{dk}$ östenitlenmiştir. Isıl işlem şartlarının malzeme özelliklerine etkisinin incelenmesi amacı ile numuneler östenitleme ișlem sonrasında farklı soğuma ortamlarında soğutulmuștur. Soğutma ortamı olarak sırası ile su, yağ, fan, hava ve fırın kullanılmıștır. Isıl işlemin sonrasında, soğuma hızına bağlı olarak malzemenin mikroyapı ve sertlik değişimlerinin incelenmesi amacı ile metalografik ve mekanik testler yapılmıştır. Çalışma sonucunda elde edilen veriler kıyaslandığında, soğuma hızının artması sonucunda ferrit oranının azaldığı ve perlit oranının arttığı gözlemlenirken, aynı zamanda sertlikte artış olduğu tespit edilmiştir.

Anahtar Kelimeler: Küresel Grafitli Dökme Demir, Isıl Işlem, Soğuma Şartları, Malzeme Özellikleri

\begin{abstract}
In this study, the effect of heat treatment conditions applied to ductile cast irons on mechanical and metallurgical properties were investigated. The chemical composition of GGG-40 ductile cast iron samples was transferred to JMatPro simulation software and TTT and CCT diagrams were obtained. Ductile cast iron samples were austenitized in a heat treatment furnace at $940^{\circ} \mathrm{C}$ for $38 \mathrm{~min}$. Water, oil, fan, air and oven are used respectively as cooling medium. After the heat treatment, metallographic and mechanical examinations were conducted to investigate the changes in microstructure and hardness of materials depending on the cooling rate. When the data obtained as a result of the study were compared; while it was observed that the ferrite ratio decreased and the pearlite ratio increased as a result of the increase in the cooling rate, at the same time increase in the hardness was determined.
\end{abstract}

Keywords: Ductile Cast Iron, Heat Treatment, Cooling Conditions, Material Properties 


\section{Giriş}

Çelikler gibi demir alaşımının geniş bir bölümü dökme demirler olup, içeriğinde $\% 2$ 'den daha fazla karbon içermektedir. Bu sebep ile demirkarbon alașımı olarak nitelendirilirler. Buna ek olarak, fazla "C" elementi, dökme demirlerin gevrekleşmesine sebep olmaktadır. Bundan dolayı ticari kullanımlarda dökme demirler için "C" oranının \%2,5-\%4 aralığında olması tercih edilmektedir. Ayrıca dökme demirler yüksek oranda $\mathrm{C}$ ve $\mathrm{Si}$ içermektedirler. Ötektik bölgede $\mathrm{Fe}_{3} \mathrm{C}$ fazı içerirler ve bu faz karbonca zengindir, bu durumda dökme demirler bu bölgede yarı kararlıdır. Kararlı durumda ise ötektik bölgede grafit fazı içerirler [1].

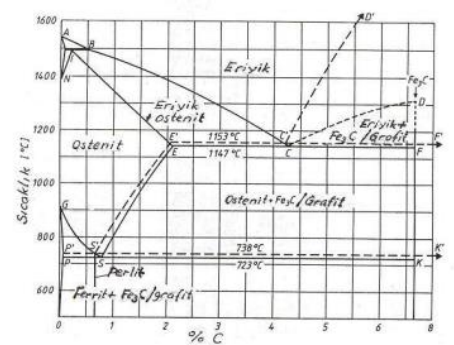

Şekil 1. Demir-karbon denge diyagramı [2]

Dökme demirler genellikle mikroyapılarına göre sinıflandırılırlar. Mikroyapı durumunu etkileyen faktörler ise, "C" oranı, alaşım elementleri veya emprüte miktarı, katılașma Tablo 1. Dökme demirlerin sınıflandırılması [6]. durumu, soğuma oranı/hızı ve ısıl ișlemdir [3, 4].

Geçmișleri en az 14. yüzyıla dayanan ve mühendislik malzemesi olan dökme demirlerin tarihsel olarak ilk sinıflandırmaları kırılma yüzeylerine göre yapılmış olup bunlar gri ve beyaz dökme demirlerdir. Akabinde, metalografide meydana gelen gelișmeler neticesinde elde edilen bilgi birikimi vasitasıly sinıflandırmalar, mikroyapı durumuna göre yapılmaya bașlamıștır [5]. Gri, beyaz, temper, küresel grafitli ve alaşımlı dökme demirler günümüzde endüstride en çok kullanılan dökme demirler olup, Tablo 1'de bunların șematik olarak gösterimi verilmiştir $[6,7]$.

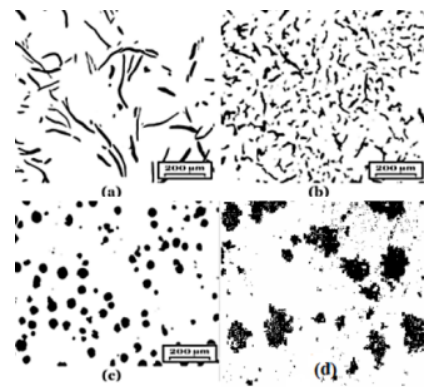

Şekil 2. Grafit yapısına göre; a)Lamel grafitli dökme demir, b)Kompakt grafitli dökme demir,

c)Küresel grafitli dökme demir d)Temper grafitli dökme demir $[8,9]$

\begin{tabular}{|c|c|c|c|c|}
\hline Ticari Adı (dökme demir) & Karbonca Zengin Faz & Matris & Kırılma Görünümü & Nihai İşlem \\
\hline Gri & Lamelli grafit & Perlit & Gri & Katılaşma \\
\hline Sünek & Küresel grafitli & $\begin{array}{l}\text { Ferrit, Perlit, } \\
\text { Östenit }\end{array}$ & Gümüş - Gri & $\begin{array}{l}\text { Katılaşma veya } \\
\text { ısıl işlem }\end{array}$ \\
\hline Yumru grafitli & $\begin{array}{l}\text { Yumru (vermiküler) } \\
\text { grafit }\end{array}$ & Ferrit, Perlit & Gri & Katılaşma \\
\hline Beyaz & Sementit & $\begin{array}{l}\text { Perlit, } \\
\text { Martenzit }\end{array}$ & Beyaz & $\begin{array}{l}\text { Katılaşma veya } \\
\text { ısıl işlem }\end{array}$ \\
\hline Benekli & Lamel grafit + sementit & Perlit & Benekli & Katılaşma \\
\hline Temper & Temperlenmiş grafit & Ferrit, Perlit & Gümüş - Gri & Isıl işlem \\
\hline Östemperlenmiş & Küresel grafit & Beynit & Gümüş - Gri & Isıl işlem \\
\hline
\end{tabular}

En eski dökme demir sınıfı, halen birçok alanda hakkında bilgi verilmiștir. Temper dökme kullanılan ve yüksek karbon içerikli karbonsilisyum alașımı olan gri dökme demirlerdir. Tablo 2'de bazı dökme demir kimyasal içeriği demirler benzer kompozisyona sahiptir, ancak süneklik özelliğinin verilebilmesi amaciyla yapıları ısıl işlem uygulamaları ile 
DEÜ FMD 23(69), 1033-1048, 2021

değiștirilmektedir. Beyaz dökme demirler ise sert ham döküm yapısındadır. Küresel grafitli dökme demirlerin ise sünekliği temper dökme demirlerinki ile benzerlik göstermektedir, ancak burada süneklik küreselleştirici alaşım elementleri ile sağlanmaktadır. Genel olarak gri ya da beyaz dökme demirlere alaşım ilavesi ile daha sert ve korozyon dayanımı daha iyi dökme demir olan alașımlı dökme demirler elde edilmektedir [6].

Bu sebeple, döküm sektörünün ilk başlangıcı gri dökme demirler olarak söylenebilir. Sonrasında küresel grafitli dökme demirler tanitılmış ve bu türün mekanik özelliklerinin çeliğe en yakın olduğu tespit edilmiștir $[7,10]$. Serbest karbonun küresel şekilde bulunduğu küresel grafitli dökme demir malzemeler "nodüler, duktil ve sfero" olarak adlandırılmaktadır. Döküm öncesi ergiyiğe az oranda $\mathrm{Mg}$ ve Ce elementi katkısı ile sementitin oluşumunun önlenmesi neticesinde küresel grafitler oluşmaktadır. Küresel grafitli dökme demirlerin kimyasal içeriği gri dökme demirlere benzemektedir, ancak az oranda kükürt ve fosfor bulunmaktadır. Temper dökme demirler ile kıyaslandığında ise küresel grafitli dökme demirlerin akma dayanımları daha iyidir. [11, $12,13,14]$.

Tablo 2. Bazı dökme demirlerin kimyasal bileşimi $[5,15]$

\begin{tabular}{|c|c|c|c|c|c|}
\hline Dökme Demir & $C$ & Si & $M n$ & $P$ & $S$ \\
\hline Gri & $2.5-4.0$ & $1.0-3.0$ & $0.2-1.0$ & $0.002-1.0$ & $0.02-0.25$ \\
\hline Yumru grafitli & $2.5-4.0$ & $1.0-3.0$ & $0.2-1.0$ & $0.01-0.5$ & $0.01-0.03$ \\
\hline Sünek & $3.0-4.0$ & $1.8-2.8$ & $0.1-1.0$ & $0.01-0.1$ & $0.01-0.03$ \\
\hline Beyaz & $1.8-3.6$ & $0.5-1.9$ & $0.25-0.8$ & $0.06-0.2$ & $0.06-0.2$ \\
\hline Temper & $2.2-2.9$ & $0.9-1.9$ & $0.15-1.2$ & $0.02-0.2$ & $0.06-0.2$ \\
\hline
\end{tabular}

Tablo 3. Küresel grafitli dökme demir ve farklı malzemelerin özellikleri (1: En iyi ve 5: En kötü) [16]

\begin{tabular}{|c|c|c|c|c|c|}
\hline Özellik & $\begin{array}{l}\text { Küresel Grafitli } \\
\text { Dökme Demir }\end{array}$ & $\begin{array}{l}\text { Temper Dökme } \\
\text { Demir }\end{array}$ & $\begin{array}{l}\text { Gri Dökme } \\
\text { Demir }\end{array}$ & $\begin{array}{l}\text { Beyaz Dökme } \\
\text { Demir }\end{array}$ & $\begin{array}{l}\text { \%0,3 Karbonlu } \\
\text { Çelik Dökümü }\end{array}$ \\
\hline Dökülebilirlik & 1 & 2 & 1 & 3 & 5 \\
\hline İşlenebilirlik & 2 & 2 & 1 & - & 3 \\
\hline Titreşim sönümleme & 2 & 2 & 1 & 5 & 4 \\
\hline Yüzey sertleştirilebilirlik & 1 & 1 & 1 & - & 3 \\
\hline Elastik modülü & 1 & 2 & 3 & - & 1 \\
\hline Darbe dayanmı & 2 & 3 & 5 & - & 1 \\
\hline Korozyon dayanımı & 1 & 2 & 1 & 5 & 4 \\
\hline Dayanım/ağırlık oranı & 1 & 4 & 5 & - & 3 \\
\hline Așınma dayanımı & 2 & 4 & 3 & 1 & 5 \\
\hline Üretim maliyeti & 2 & 3 & 1 & 2 & 4 \\
\hline
\end{tabular}

Küresel grafitli dökme demirlerin ayrıca; yüksek, üretim maliyeti az, așınma ve korozyon akışkanlık özelliği iyi, şekil alabilme kabiliyeti dayanımı iyidir ve kompleks şekillerde üretime 
imkan vermektedir. $\mathrm{Bu}$ sebep ile yapısal uygulamalarda ve otomotiv sektöründe olmak üzere daha pek çok endüstriyel alanlarda sahip oldukları özellikler sebebi ile tercih edilmekte ve kullanılmaktadır [17].

Uygulanan isıl işlem prosesleri ile küresel grafitli dökme demirlerin üstün özelliklere sahip olması sağlanmaktadır. Küresel grafitli dökme demirlere uygulanmakta olan isıl işlemler; gerilim giderme tavlaması, yumuşatma tavlaması, normalizasyon, su verme ve islah etme, östemperleme olmak üzere siralanmaktadır [2].

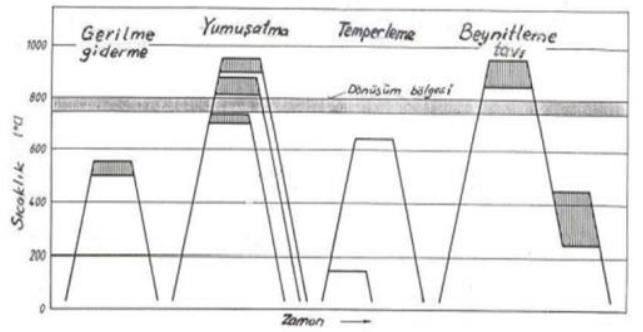

Şekil 3. Dökme demir ısıl işlem prosesleri ve sıcaklık-zaman grafiği [2]

Küresel grafitli dökme demirlere uygulanan ısıl işlemler için geçerli olan sıcaklık-zaman grafiği Şekil 3'teki gibidir. Dökme demirler için uygulanmakta olan ısıl işlemlerin çeliğinkine benzediği Șekil 3'te de görülmektedir. Ancak, dökme demir kimyasal kompozisyonunda bulunan farklı alaşım elementleri dönüşümü kararlı veya yarı-kararlı kılmaktadır ve alaşım elementleri bu durumu etkilemektedir. Böylece dökme demirlerin isıl ișlemi çeliklerinkinden farklılık göstermektedir. Buna ek olarak, dökme demirlerde bağlı karbon elementi, uygun sıcaklıkta grafit formunda ayrıșmaktadır [2].

Küresel grafitli dökme demirlerde dönüşüm çeliklere benzemektedir. Dönüşüm östenitten ferrit ve perlite doğru ilerlemektedir. Ancak yapı oluşumu çelikten farklıdır ki ferrit ile perlit oluşum miktarı difüzyon kontrollüdür. Alaşım elementi türü ve miktarı, zaman, sıcaklık ve soğuma hızı difüzyon hızını etkilemektedir. Döküm şartlarında elde edilemeyen mikro-yapı ısıl işlem ile elde edilmesi durumunda hem ısıtma hem de soğutma esnasında oluşan yapı değișimi detaylı incelenmelidir [18].

Küresel grafitli dökme demirlerde katılaşma esnasında gözlenen yapı östenittir. Bu sırada, kalıntı ve yapı içinde çözünen maksimum karbon miktarının fazlası grafit olarak ayrıșır. Östenitteki karbon çözünürlüğü sicaklığın düşmesiyle azalmaktadır. Bu nedenle, östenit fazından ayrılan karbon difüze olup grafit şeklini almaktadır. Ayrıldığı bölgeyi karbonsuzlaştırmaktadır ve böylece ferrit fazı meydana gelmektedir. Yüksek uzama kapasitesine sahip olan ferrit fazının oluşumu perlit fazına nazaran yüksek sıcaklıkta olmaktadır. Ferrit ile perlitin birbiri ile oranı kimyasal kompozisyon ile soğuma hızından etkilenmektedir, ayrıca bu durum malzemenin akma ve çekme dayanımı, sertlik ve uzama gibi bazı özelliklerini doğrudan etkilemektedir [15].

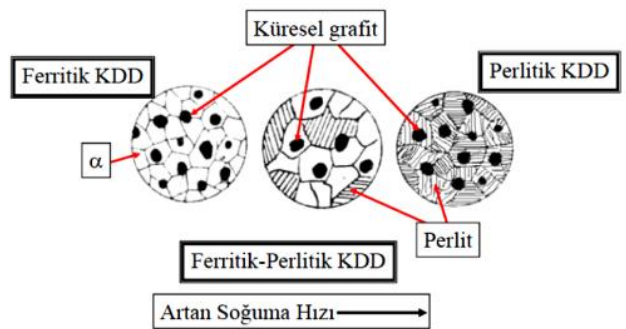

Șekil 4. Soğuma hızının dökme demirlere etkisi [19]

Temper ya da östenitleme sıcaklığına çıkarılan küresel grafitli dökme demir ürünlerin soğuması esnasında meydana gelen dönüșüm, soğuma hızından etkilenmektedir. Soğuma hızının artması ile Şekil 4'te görüldüğü gibi malzeme mikroyapısı tamamen değișmektedir [18].

Fırında yavaș soğutma esnasında, soğuma hızı difüzyonun sürekliliğine olanak sağlamaktadır ve bu esnada ferrit fazı meydana gelmektedir. Havada soğutma şartlarında ise, soğuma hızı genel olarak difüzyona az oranda imkan sağlamaktadır ve ısıtma esnasında olușan yapı daha az miktarda değişmektedir. Östenitleme sıcaklığına çıkarılmıș malzemenin havada soğuma şartlarındaki soğuma hızı, genellikle kalıp içerisinde olușan katılașma sonrasındaki soğuma hızına göre daha yüksek olmaktadır. Buna ek olarak grafit haricinde ana yapı dönüşmektedir. $\mathrm{Bu}$ kapsamda sadece mikroyapısal olarak etki göstermekte ve bununla birlikte malzemenin mekanik özellikleri tamamen değişmektedir. Örneğin, hava ortamında soğumuş parçanın perlit miktarı, döküm şartlarında sağlanmış perlit miktarına göre daha yüksek olup, perlitik 
küresel grafitli dökme demir sert ve kırılgan özellik gösterir iken, ferritik küresel grafitli dökme demir sünektir [18].

Bu çalışmada, deney numunesi olarak kullanılan GGG 40 kalite küresel grafitli dökme demirlerin farklı soğuma hızlarındaki mikroyapı ve sertliğe etkilerinin araştırılması amaçlanmıștır. $\mathrm{Bu}$ kapsamda $940^{\circ} \mathrm{C}$ sıcaklıkta $38 \mathrm{dk}$ östenitlenen deney numuneleri sırası ile fırında, havada, fanda, yağda ve suda soğutulmuștur. Akabinde, mikro sertlik testleri yapılmıs ve buradan elde edilen değerler ile sertlik-mukavemet dönüşüm formülünden yararlanılarak çekme mukavemet değerleri de elde edilmiştir. Deneysel çalışmaların devamında metalografik incelemeler yapılmıştır. Elde edilen veriler karşılaştırılmış ve soğuma hızının etkileri incelenmiştir.

\section{Materyal ve Metot}

Deneysel çalıșmalarda, materyal olarak GGG 40 kalite küresel grafitli dökme demir kullanılmış olup, numuneye ait boyut bilgileri Sekil 5 'te verilmiștir.

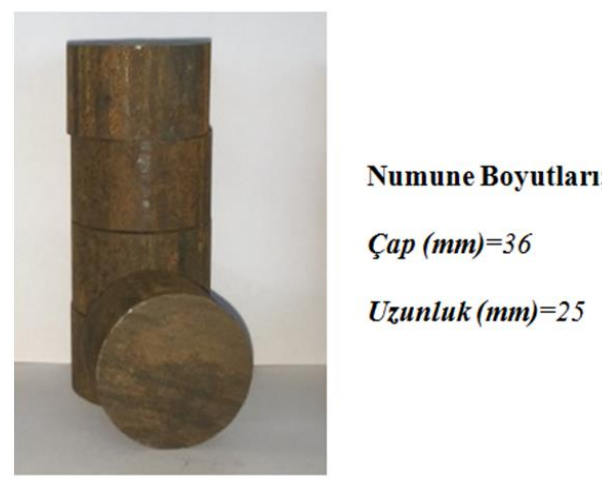

Şekil 5. GGG 40 kalite küresel grafitli dökme demir numunelere ait boyut bilgileri

Deney numunelerine ait kimyasal kompozisyon detayları Tablo 4'de ve mekanik özelliklerine ait detaylar ise Tablo 5'te verilmiştir.

Tablo 4. Döküm malzeme spektral analizi

\begin{tabular}{lllllllll}
\hline Alaşım Elementi & $C$ & $S i$ & $S$ & $C r$ & $C u$ & $M n$ & $M g$ & $P$ \\
\hline \% Ağırlıkça & 3,725 & 2,900 & 0,010 & 0,050 & 0,059 & 0,240 & 0,074 & 0,105 \\
\hline
\end{tabular}

Tablo 5. Döküm malzeme mekanik özellikleri

\begin{tabular}{|c|c|}
\hline Clekme mukavemeti (MPa) & $\operatorname{Sertlik}(H B)$ \\
\hline 382 & 13,1 \\
\hline $\begin{array}{l}\mathrm{Bu} \text { çalıșmada; ısıl işlem çalışmaları ve } \\
\text { laboratuvar incelemeleri yapılmıştır. } \\
\text { 2.1. Simülasyon Analizleri }\end{array}$ & $\begin{array}{l}\text { numunelerinin östenitleme işlemleri için } \\
\text { Protherm marka elektrikli ısı işlem firını } \\
\text { kullanılmıştır. }\end{array}$ \\
\hline $\begin{array}{l}\text { Bu çalışmada, deney malzemesinin farklı } \\
\text { soğuma şartları altındaki TTT ve CCT } \\
\text { diyagramlarının elde edilebilmesi amacı ile } \\
\text { JMatPro yazılımı kullanılmıştır. Bu kapsamda } \\
\text { deney numunesinin kimyasal kompozisyonuna } \\
\text { ait } 1^{\circ} \mathrm{C} / \mathrm{s}, 3^{\circ} \mathrm{C} / \mathrm{s} \text { ve } 5^{\circ} \mathrm{C} / \mathrm{s} \text { soğutma hızlarında } \\
\text { simülasyon analizi yapılmıştır. }\end{array}$ & $\begin{array}{l}\text { Fırında bekletme süresinin hesabı için } \\
\text { "Bekletme Süresi = D/2+20 (Dakika)" formülü } \\
\text { kullanılmış olup, "D" mm cinsinden numune } \\
\text { çapını belirtmektedir [20]. Bu kapsamda, ısıl } \\
\text { işlem uygulamaları için; Şekil } 5^{\prime} \text { te verilen } 36 \\
\text { mm çaptaki deney numuneleri, } 15,67^{\circ} \mathrm{C} / \mathrm{dk} \text { hız } \\
\text { ile } 940^{\circ} \mathrm{C} \text { östenitleme sıcaklığına çıarılmış }\end{array}$ \\
\hline 2.2. Isıl İşlem Çalışmaları & $\begin{array}{l}\text { akabinde tavlama süresi formülü ile hesaplanan } \\
38 \mathrm{dk} \text { süresince tavlanmıștır. Tavlama ișlemi }\end{array}$ \\
\hline $\begin{array}{l}\text { Isıl işlem çalışmalarında Şekil } 5 \text { 'te boyutu } \\
\text { verilen ve } 5 \text { farklı soğuma ortamı için 3'er adet } \\
\text { olmak üzere } 15 \text { adet GGG } 40 \text { kalite küresel } \\
\text { grafitli dökme demir numuneler kullanılmıştır. } \\
\text { Burada, soğutma ortamı olarak firın, hava, fan, }\end{array}$ & 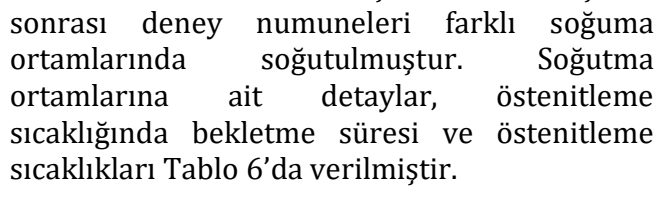 \\
\hline
\end{tabular}


DEÜ FMD 23(69), 1033-1048, 2021

Tablo 6. Soğutma Ortamlarına Ait Detaylar

\begin{tabular}{|c|c|c|c|c|}
\hline $\begin{array}{l}\text { Soğutma } \\
\text { Ortamı }\end{array}$ & $\begin{array}{l}\text { Soğutmaya Ait Kullanılan Şartlar ve } \\
\text { Ekipmanlar }\end{array}$ & $\begin{array}{l}\text { Numune } \\
\text { Sayıs }\end{array}$ & $\begin{array}{l}\text { Östenitleme } \\
\text { Sıcaklığı }\left({ }^{\circ} \mathrm{C}\right)\end{array}$ & $\begin{array}{l}\text { Bekleme } \\
\text { Süresi (Dk) }\end{array}$ \\
\hline $\mathrm{Su}$ & $20^{\circ} \mathrm{C}$ şebeke suyu & 3 & $940^{\circ} \mathrm{C}$ & 38 \\
\hline Yağ & “Total Azolla ZS 68” marka yağ & 3 & $940^{\circ} \mathrm{C}$ & 38 \\
\hline Fan & $\begin{array}{l}25^{\circ} \mathrm{C} \text { ortam havasında } 1 \times 3400 \mathrm{~m}^{3} / \mathrm{h} \text { debili } \\
\text { endüstriyel fan }\end{array}$ & 3 & $940^{\circ} \mathrm{C}$ & 38 \\
\hline Hava & $25^{\circ} \mathrm{C}$ ortam havasında & 3 & $940^{\circ} \mathrm{C}$ & 38 \\
\hline Firın & Protherm marka ısıl ișlem fırını & 3 & $940^{\circ} \mathrm{C}$ & 38 \\
\hline
\end{tabular}

\subsection{Laboratuvar Çalıșmaları}

Isıl işlemden sonra farklı soğuma hızları ile soğutulan deney numunelerinin sertlik değişimlerinin belirlenmesi amacı ile deney numunelerine Qness marka Q10 model cihaz ile vickers-sertlik testi uygulanmıştır. Sertlik ölçümleri Şekil 6'da verilen doğrultuda 0,2 mm'lik aralıklar ile numuneye $1 \mathrm{~kg}$ yük uygulanarak gerçekleștirilmiştir. Ölçüm öncesinde numuneler metalografik numune hazırlama yöntemi ile hazırlanmıştır.

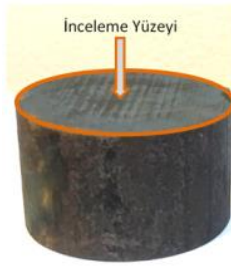

(a)

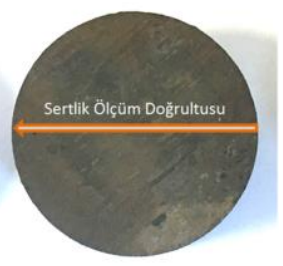

(b)
Şekil 6. (a) İnceleme yüzeyi ve (b) Sertlik ölçüm doğrultusu

Farklı soğuma hızlarının çekme mukavemetine etkisinin incelenebilmesi amacl ile sertlikçekme mukavemetine ait verilen ilişkiden yararlanılmıştır. $\mathrm{Bu}$ kapsamda, elde edilen vickers sertlik değerleri sertlik dönüșüm tablosu kullanılarak brinell sertlik değerleri elde edilmiștir.

Şekil 7'deki grafikte görüldüğü gibi, brinel sertlik değeri çekme dayanımı ile orantılıdır. Birçok çelik için brinel sertlik-çekme dayanımı dönüşüm formülü aşağıda verilmiştir [21].

$$
T S(M P a)=3,4 \times H B
$$

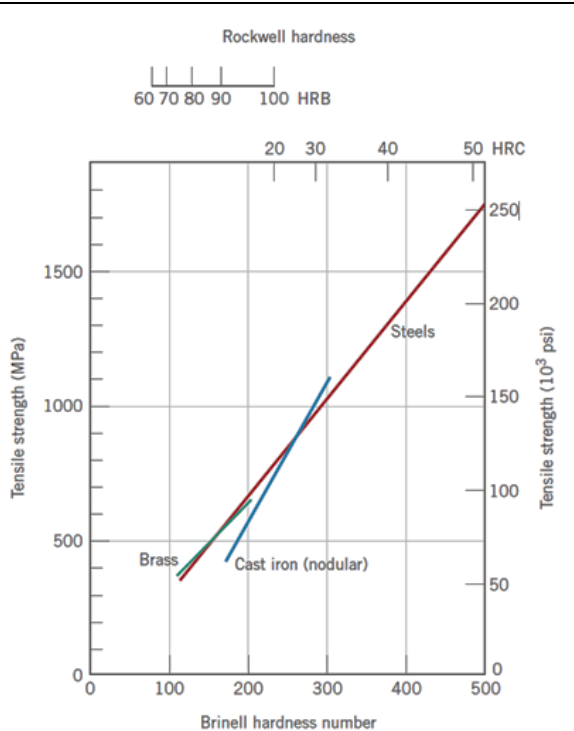

Şekil 7. Sertlik ve çekme dayanımı ilişkisi [22]

Denklem 1'deki formül çeliklere ait olduğundan dolayı, bu çalıșmada dökme demirlerin sertlikçekme mukavemeti dönüşümü hesabının yapılabilmesi amacı ile dökme demir için verilen eğriden, eğim elde edilmiștir. Dökme demirlere ait sertlik-mukavemet dönüşüm formülünün elde edilebilmesi amacı ile iki noktası bilinen doğrunun eğimi formülü kullanılmıştır. Formülde hesabın gerçekleştirilebilmesi amacı ile dökme demir için verilen eğrinin herhangi bir noktası ve elde edilen eğim kullanılmıștır. Burada kullanılan $(\mathrm{x}, \mathrm{y})$ nokta $(200,590)$ noktasıdır. 


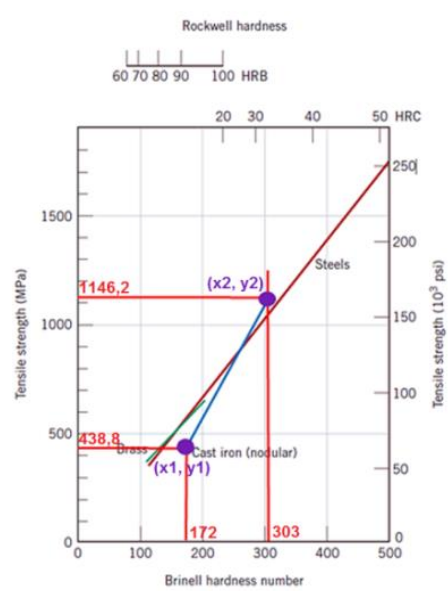

Şekil 8. Dökme demirlerin sertlik-çekme mukavemeti dönüşümü hesabı için gerekli noktaların gösterimi

Dökme demirler için eğimin hesaplanması;

$$
\begin{aligned}
& m=\frac{y_{2}-y_{1}}{x_{2}-x_{1}} \\
& m=\frac{1146,2-438,8}{303-172}=5,4
\end{aligned}
$$

Dökme demir için sertlik- mukavemet dönüşüm formülünün bulunması;

$$
\begin{aligned}
& y-y^{\prime}=m\left(x-x^{\prime}\right) \\
& y-590=5,4(x-200) \\
& y=5,4 x-490 \\
& T S(M P a)=5,4 H B-490
\end{aligned}
$$

Farklı soğuma hızlarında soğutulan küresel grafitli dökme demirlerin soğuma hızına bağlı olarak faz dağılımında ve mikroyapısındaki değişimlerin belirlenmesi amacı mikroyapısal incelemeler yapılmıştır. Mikroyapısal inceleme öncesinde numuneler sırası ile, sicak bakalitleme cihazında bakalite alınmış, parlatma cihazında $120,240,320,600,800$ ve 1200 grid'lik zımparalarda zımparalanmıș ve sonrasında $3 \mu \mathrm{m}$ 'luk alümina pasta ile parlatılmıştır. Parlatma işlemi sonrasında numuneler \%2 nital çözeltisinde dağlanmıștır. Numune hazırlama işlemlerinden sonra mikroyapı görüntüleri optik mikroskop ile Şekil 10 'da verilmiş olan bölgelerden 100x büyütme yapılarak alınmıştır.

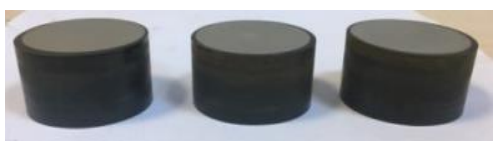

Şekil 9. Mikroyapı incelemeleri için hazırlanan numuneler

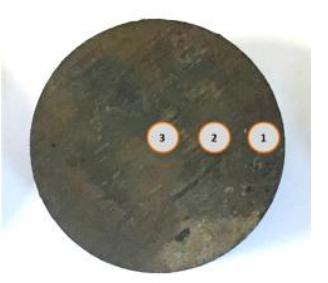

Şekil 10. Mikroyapı inceleme bölgeleri

\section{Bulgular}

\subsection{Simülasyon Analizi Sonuçları}

Farklı soğuma hızlarına ait yapılan simülasyon analizi sonucunda elde edilen TTT ile CCT diyagramları Şekil 11 ve 12'de verilmiştir.

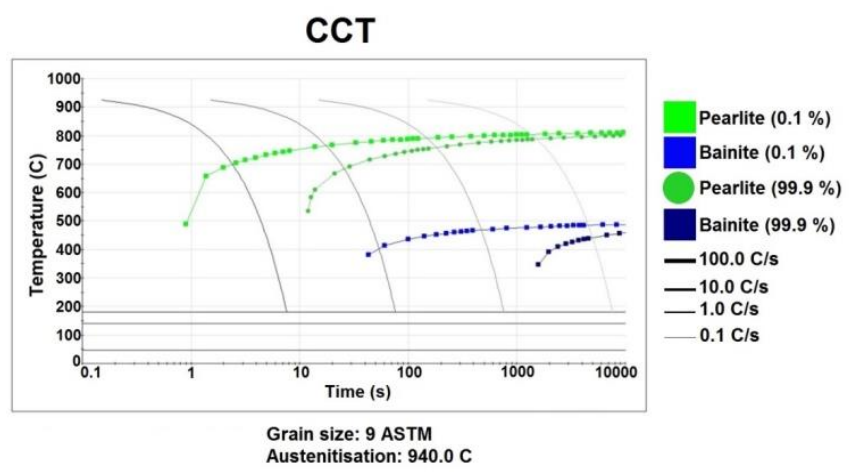

Şekil 11. JMatPro yazılımı ile elde edilen CCT diyagramı 


\section{TTT}

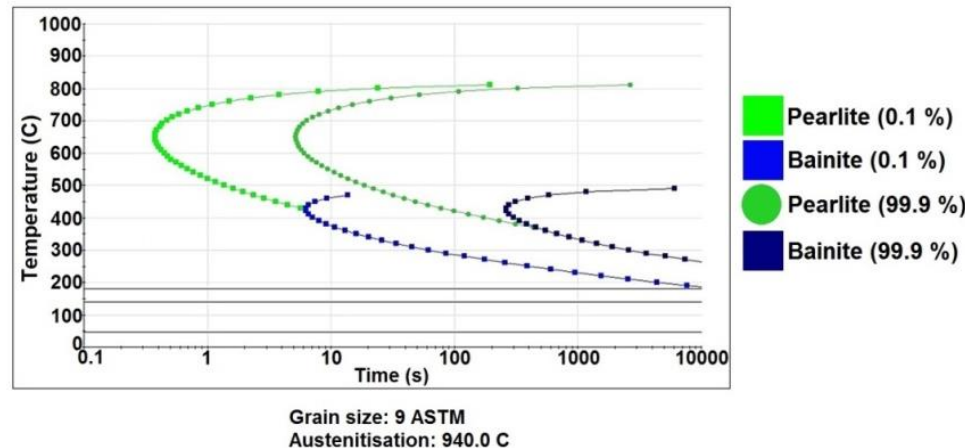

Şekil 12. JMatPro yazılımı ile elde edilen TTT diyagramı

\subsection{Simülasyon Analizi Sonuçları}

$940^{\circ} \mathrm{C}$ sıcaklıkta östenitlenen parçaların farklı soğuma ortamlarına ait soğuma hızlarının belirlenmesi aşamasında pirometre ile sıcaklık ölçümleri gerçekleştirilmiştir. Süreye bağlı olarak ölçülen sıcaklıklara göre hesaplanan soğuma hızları Tablo 7'de verilmiştir.
Tablo 7. Soğuma hızları

\begin{tabular}{llllll}
$\begin{array}{l}\text { Soğutma } \\
\text { Ortamı }\end{array}$ & Su & Yağ & Fan & Hava & Fırın \\
\hline $\begin{array}{l}\text { Soğuma } \\
\text { Hızı } \\
\left({ }^{\circ} \mathrm{C} / \mathrm{sn}\right)\end{array}$ & 10,44 & 4,48 & 1,04 & 0,31 & 0,16 \\
\hline
\end{tabular}

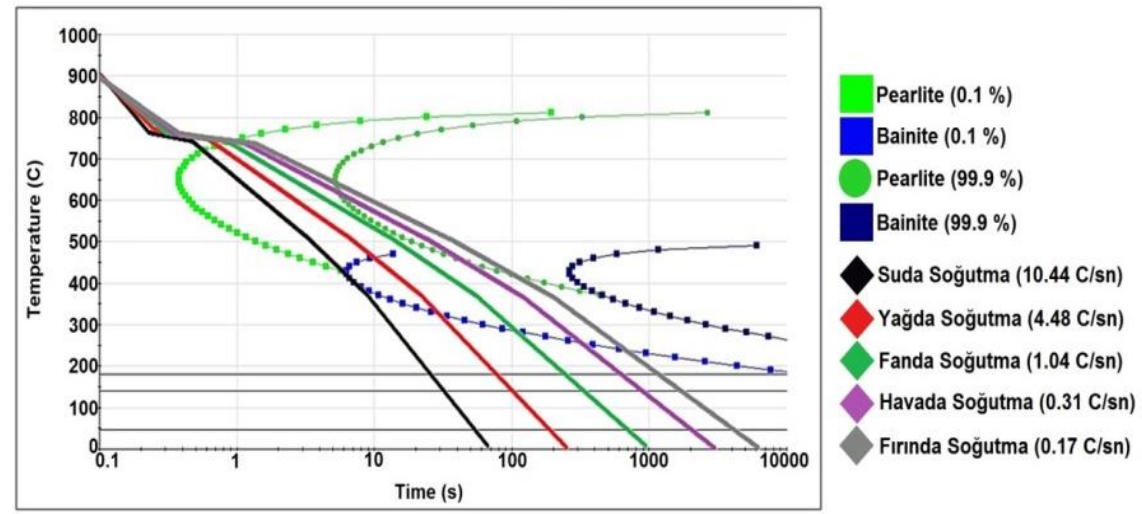

Şekil 13. Deney ile elde edilen soğuma eğrilerinin TTT üzerine çizimi

\subsection{Laboratuvar Çalışma Sonuçları}

$940^{\circ} \mathrm{C}$ 'de 38 dakika süre ile östenitlenen numuneler farklı soğuma hızlarında soğutulması akabinde yapılan vickers sertlik deneyleri sonucunda suda soğutulan numunelerin sertlik değerlerinin en yüksek olduğu belirlenmiş olup, soğuma hızının azalması ile sertlik değerlerinde düşüş yaşandığı ve soğuma hızının artması ile sertlik değerlerinde artış yaşandığı belirlenmiştir.

Elde edilen vickers sertlik değerleri, sertlik dönüşüm tablosundan yararlanılarak brinell sertlik değerlerine dönüștürülmüștür. Farklı soğuma hızlarına ait elde edilen ortalama vickers ve brinell sertlik değerleri Tablo 8'de verilmiştir. 
DEÜ FMD 23(69), 1033-1048, 2021

Tablo 8. Farklı soğuma hızlarında elde edilen ortalama sertlik değerleri

\begin{tabular}{|c|c|c|c|c|c|c|c|}
\hline \multirow[t]{2}{*}{ Soğutma Ortamı } & \multirow{2}{*}{$\begin{array}{l}\text { Soğutma Hızı } \\
\left({ }^{\circ} \mathrm{C} / \mathrm{sn}\right)\end{array}$} & \multicolumn{3}{|c|}{ Vickers Sertlik Değerleri } & \multicolumn{3}{|c|}{ Brinell Sertlik Değerleri } \\
\hline & & Max. & Min. & Ort. & Max. & Min. & Ort. \\
\hline Suda soğutma & 10,44 & 678,33 & 396,33 & 518,49 & 644,80 & 376,74 & 492,51 \\
\hline Yağda soğutma & 4,48 & 556,33 & 283,33 & 403,12 & 528,83 & 268,38 & 383,09 \\
\hline Fanda soğutma & 1,04 & 355,33 & 235,67 & 290,99 & 337,77 & 224,02 & 276,61 \\
\hline Havada soğutma & 0,31 & 305,00 & 173,00 & 219,25 & 289,92 & 164,45 & 208,41 \\
\hline Fırında soğutma & 0,17 & 186,33 & 159,33 & 171,60 & 177,12 & 151,46 & 163,12 \\
\hline
\end{tabular}

Tablo 8'de verilen değerler incelendiğinde, Yapılan vickers sertlik deneyinden elde edilen soğuma hızının artması ile sertlik değerlerinin arttığı ve bu durumun soğumaya bağlı olarak malzeme içyapısında beynitik fazın oluştuğu öngörülmektedir. Ayrıca buna etken diğer bir durum ise, soğuma hızına bağlı olarak küçülen tane boyutlarıdır. Tane boyutlarındaki küçülme sebebi ile tane sinırları artmakta ve artan tane sınırları dislokasyon hareketlerini zorlamaktadır. $\mathrm{Bu}$ sebeple tane sınırlarında dislokasyon yığılmaları görülebilir. Buna ek olarak sertliğin artması ile birlikte vickers sertlik değerlerinin brinell sertlik dönüșümünden sonra çekme mukavemetinin elde edilebilmesi amacı ile öncelikle Denklem 1 'e göre hesaplama yapılmıştır. Ancak Denklem 1 genel olarak çeliklerde kullanıldığından dolayı, dökme demirler için elde edilen ve Denklem 2'de verilen sertlik-çekme mukavemeti formülü kullanılmıș ve çekme mukavemeti değerleri elde edilmiştir. Elde edilen değerler Tablo 9'de verilmiștir. mukavemette de artıș gözlemlenir.

Tablo 9. Sertlik değerleri kullanılarak formüle dayalı hesaplanan çekme mukavemeti değerleri Soğutma Ortamı Soğutma Hızı Çekme Muk. Çekme Muk. $\left({ }^{\circ} \mathrm{C} / \mathrm{sn}\right) \quad[\mathrm{TS}(\mathrm{Mpa})=3,45 \times \mathrm{HB}]$

$[T S(M p a)=(5,4 \times H B)-490]$

\begin{tabular}{llllllll} 
& & Max. & Min. & Ort. & Max. & Min. & Ort. \\
\cline { 3 - 7 } Suda soğutma & 10,44 & 2224,57 & 1299,76 & 1699,17 & 2991,94 & 1544,41 & 2169,56 \\
Yağda soğutma & 4,48 & 1824,47 & 925,90 & 1321,66 & 2365,69 & 959,24 & 1578,69 \\
Fanda soğutma & 1,04 & 1165,29 & 772,86 & 954,30 & 1333,94 & 719,70 & 1003,69 \\
Havada soğutma & 0,31 & 1000,24 & 567,35 & 719,01 & 1075,59 & 398,02 & 635,41 \\
Firında soğutma & 0,17 & 611,07 & 522,53 & 562,75 & 466,46 & 327,87 & 390,83
\end{tabular}

Uygulanan ısıl işlemin sonrasında farklı soğutma hızlarında soğutulan numunelerde oluşan mikroyapı değişimlerinin incelenebilmesi amacıyla yapılan mikroyapı inceleme sonuçları Şekil 14 ile Şekil 18 aralığında verilmiştir. Mikroyapı görüntüleri incelendiğinde, resimlerde açı renk ile belirtilen bölgeler ferrit fazını, koyu renk ile belirtilen bölgeler perlit fazını ve küre formundaki yapılar ise grafiti ifade eder. Artan soğuma hızı ile ferrit fazı azalırken perlit fazı artış eğilimindedir. Aynı zamanda soğuma hızına göre tane morfolojisinin değiştiği ve yapının iğnemsi bir hale geçtiği tespit edilmiştir. $\mathrm{Bu}$ durum özetlenecek olursa, soğuma hızının artması ile yapı ferrit fazından ferrit+beynite doğru değișim göstermektedir. 

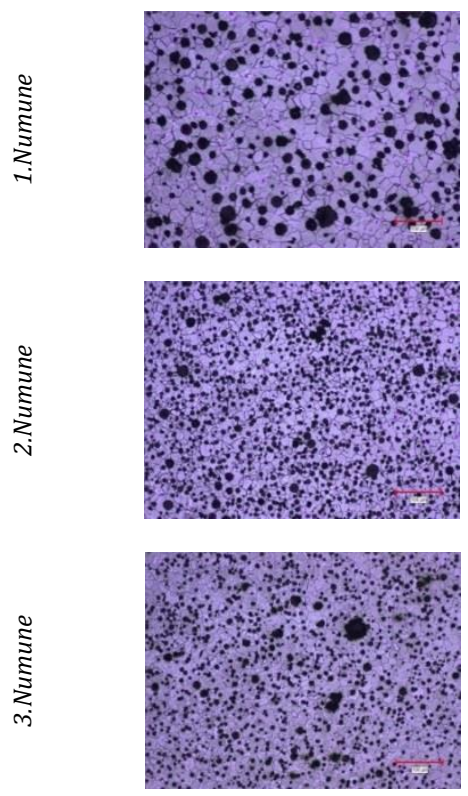

(a)
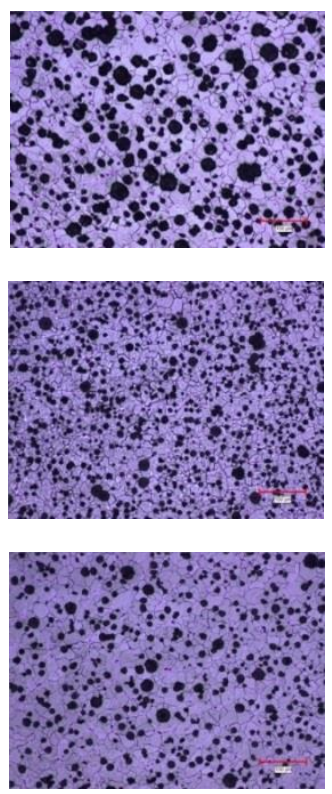

(b)
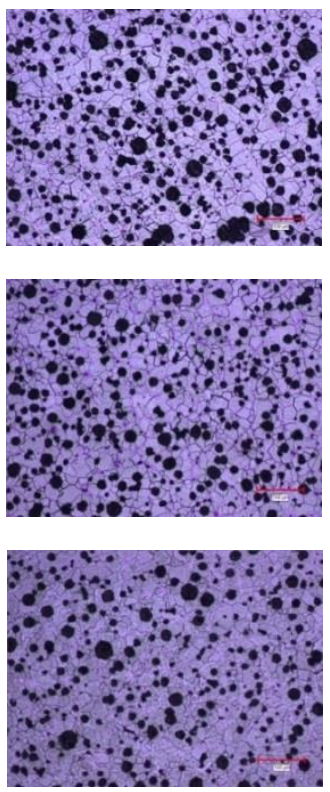

(c)

Şekil 14. Fırında soğutulan numunelerin dağlanmış yüzeyinden alınan $100 x$ büyütmedeki görüntüleri; (a) 1.bölge, (b) 2.bölge ve (c) 3.bölge
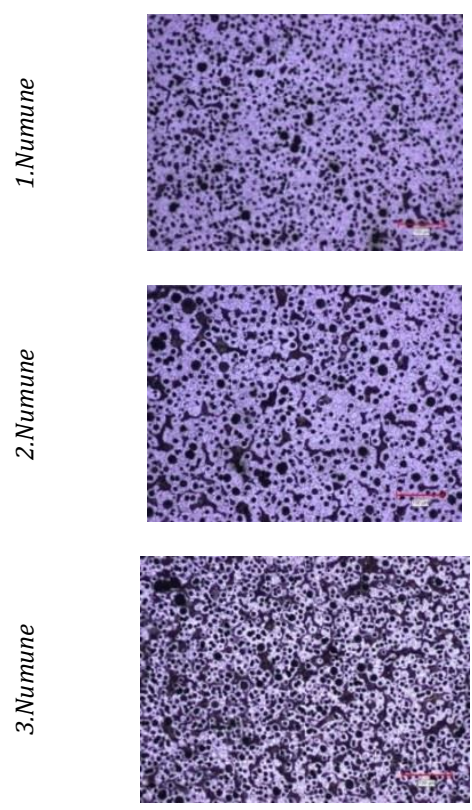

(a)
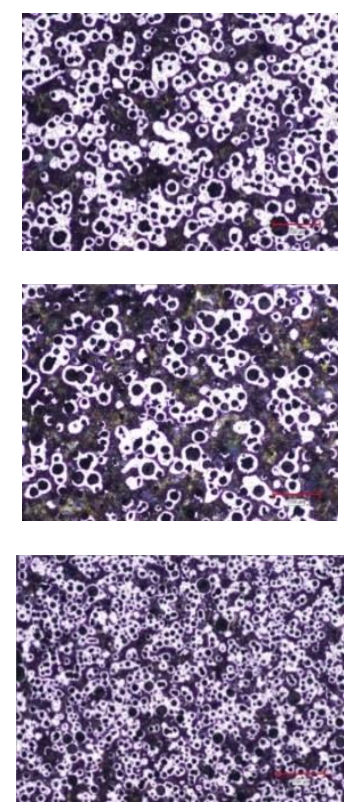

(b)
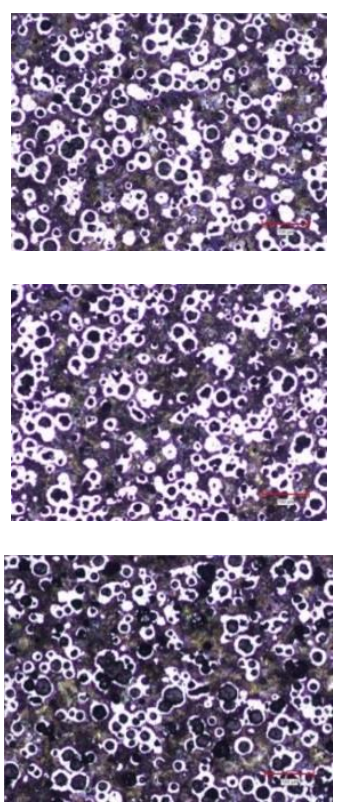

(c)

Şekil 15. Havada soğutulan numunelerin dağlanmıș yüzeyinden alınan 100x büyütmedeki görüntüleri; (a) 1.bölge, (b) 2.bölge ve (c) 3.bölge 
DEÜ FMD 23(69), 1033-1048, 2021
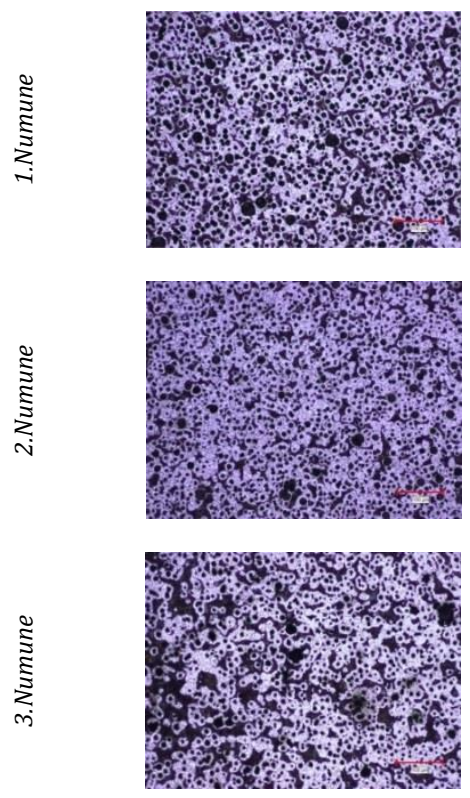

(a)
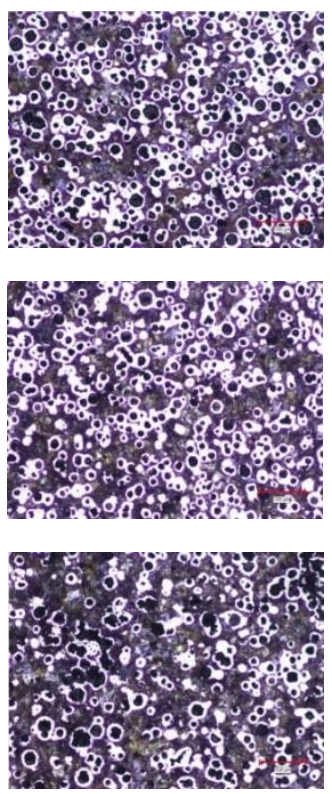

(b)
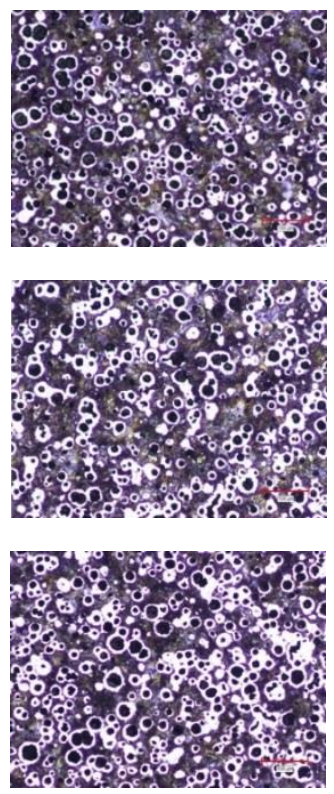

(c)

Şekil 16. Fanda soğutulan numunelerin dağlanmış yüzeyinden alınan 100x büyütmedeki görüntüleri; (a) 1.bölge, (b) 2.bölge ve (c) 3.bölge
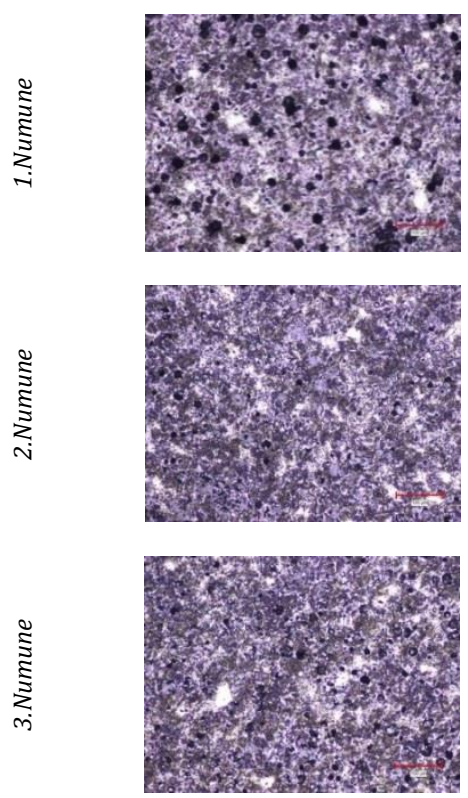

(a)
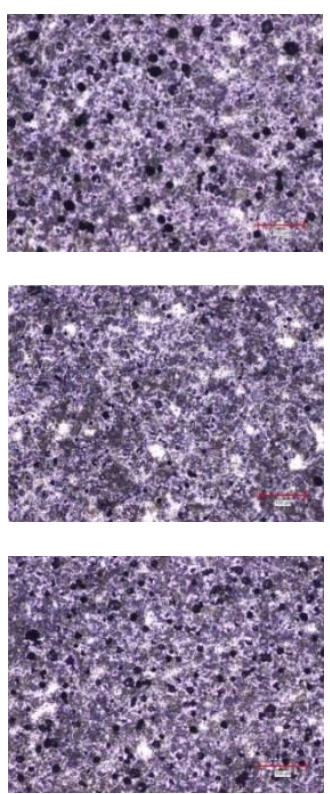

(b)
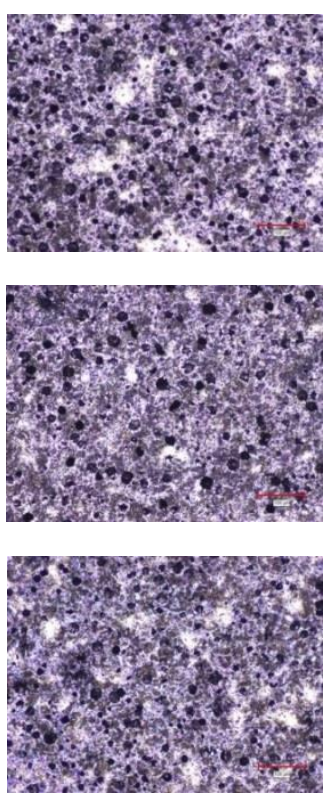

(c)

Şekil 17. Yağda soğutulan numunelerin dağlanmış yüzeyinden alınan 100x büyütmedeki görüntüleri; (a) 1.bölge, (b) 2.bölge ve (c) 3.bölge 

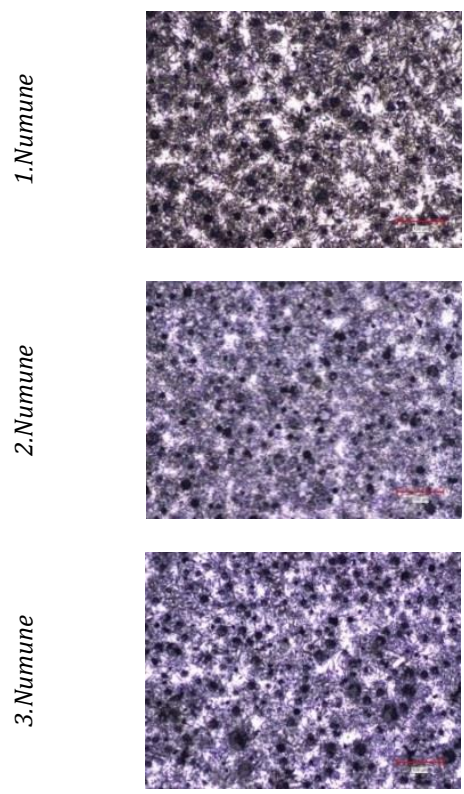

(a)
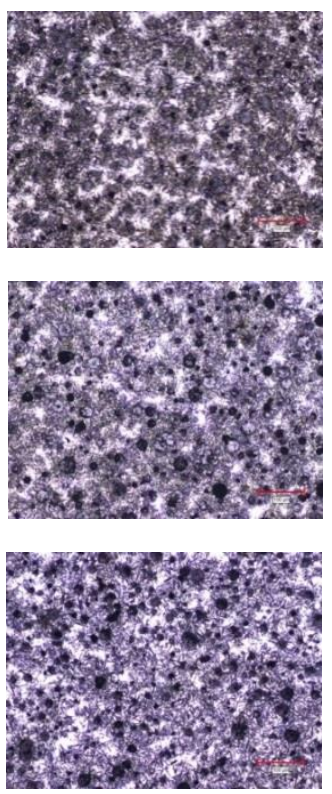

(b)
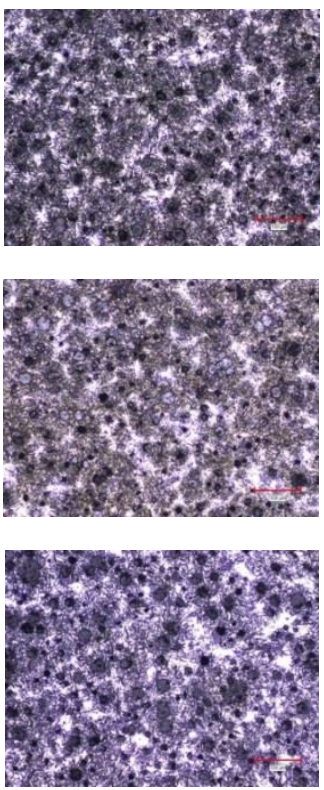

(c)

Şekil 18. Suda soğutulan numunelerin dağlanmış yüzeyinden alınan 100x büyütmedeki görüntüleri; (a) 1.bölge, (b) 2.bölge ve (c) 3.bölge

Faz dağılımının tespit edilmesi amacı ile mikroyapı incelemeleri sonucunda elde edilen görüntüler kullanılmış olup, faz dağılımları Material Plus yazılımı ile ölçülmüștür. Ancak program perlit fazı ile grafiti aynı faz olarak belirlediğinden dolayı, numunelerin parlatılmış yüzeyinden alınan görüntüler ile grafit yüzdeleri belirlenmiștir. Elde edilen bu değer, dağlanmış yüzeyden tespit edilen grafit+perlit yüzdesinden çıarılarak gerçek perlit yüzdesi hesaplanmıştır. Yapılan ölçümler sonucunda elde edilen değerler yüzde olarak Tablo 10 ile Tablo 14 arasında verilmiștir.

Tablo 10. Suda soğutma ortamında $10,44^{\circ} \mathrm{C} / \mathrm{sn}$ hız ile soğutulan numunelere ait faz dağılımları

\begin{tabular}{lcccc}
\hline Faz & 1.Nokta & 2.Nokta & 3.Nokta & Ortalama \\
\hline Ferrit & 34,00 & 33,55 & 32,78 & 33,44 \\
$\begin{array}{l}\text { Perlit+ } \\
\text { Grafit }\end{array}$ & 66,00 & 66,45 & 67,22 & 66,56 \\
Grafit & 14,03 & 16,56 & 17,81 & 16,14 \\
Perlit & 51,97 & 49,89 & 49,41 & 50,42 \\
\hline
\end{tabular}

Tablo 11. Yağda soğutma ortamında $4,48^{\circ} \mathrm{C} / \mathrm{sn}$ hız ile soğutulan numunelere ait faz dağılımları

\begin{tabular}{lcccc} 
Faz & 1.Nokta & 2.Nokta & 3.Nokta & Ortalama \\
\hline Ferrit & 35,94 & 35,40 & 34,98 & 35,44 \\
$\begin{array}{l}\text { Perlit+ } \\
\text { Grafit }\end{array}$ & 64,06 & 64,60 & 65,02 & 64,56 \\
Grafit & 18,40 & 19,23 & 19,77 & 19,13 \\
Perlit & 45,66 & 45,37 & 45,25 & 45,43 \\
\hline
\end{tabular}

Tablo 12. Fanda soğutma ortamında $1,048^{\circ} \mathrm{C} / \mathrm{sn}$ hız ile soğutulan numunelere ait faz dağılımları

\begin{tabular}{lllll}
\hline Faz & 1.Nokta & 2.Nokta & 3.Nokta & Ortalama \\
\hline Ferrit & 51,43 & 39,59 & 41,25 & 44,09 \\
$\begin{array}{l}\text { Perlit+ } \\
\text { Grafit }\end{array}$ & 48,57 & 60,41 & 58,76 & 55,91 \\
Grafit & 18,87 & 15,02 & 21,98 & 18,63 \\
Perlit & 29,70 & 45,39 & 36,77 & 37,29 \\
\hline
\end{tabular}


DEÜ FMD 23(69), 1033-1048, 2021

Tablo 13. Havada soğutma ortamında $0,31^{\circ} \mathrm{C} / \mathrm{sn}$ hız ile soğutulan numunelere ait faz dağılımları

\begin{tabular}{lllll}
\hline Faz & 1.Nokta & 2.Nokta & 3.Nokta & Ortalama \\
\hline Ferrit & 65,27 & 48,90 & 43,53 & 52,57 \\
$\begin{array}{l}\text { Perlit+ } \\
\text { Grafit }\end{array}$ & 34,73 & 51,10 & 56,47 & 47,43 \\
Grafit & 19,14 & 16,60 & 18,64 & 18,13 \\
Perlit & 15,58 & 34,50 & 37,83 & 29,30 \\
\hline
\end{tabular}

Tablo 14. Firında soğutma ortamında $0,17^{\circ} \mathrm{C} / \mathrm{sn}$ hız ile soğutulan numunelere ait faz dağılımları

\begin{tabular}{lllll}
\hline Faz & 1.Nokta & 2.Nokta & 3.Nokta & Ortalama \\
\hline Ferrit & 78,01 & 76,83 & 76,14 & 77,00 \\
$\begin{array}{l}\text { Perlit+ } \\
\text { Grafit }\end{array}$ & 21,98 & 23,17 & 23,86 & 23,00 \\
Grafit & 16,51 & 19,53 & 20,70 & 18,91 \\
Perlit & 5,47 & 3,64 & 4,40 & 4,50 \\
\hline
\end{tabular}

Malzeme tane boyutunun sayısal olarak tespit edilmesine ASTM E112 standardından yararlanılmıştır. Tespit edilen ASTM tane boyut numarası, tane büyüklüğü ile ilgili bilgi verir. Bundan dolayı, bu çalışmada mikroyapı incelemeleri neticesinde elde edilen görüntüler kullanılarak Material Plus yazılımı vasıtası ile ASTM tane boyutu numaraları hesaplanmıștır.

Elde edilen ASTM tane boyutu numaraları kullanılan 100x büyütmede 1 inch $^{2}$ deki toplam tane sayısı tespiti için aşağıdaki formül kullanılarak toplam tane sayısı belirlenmiştir.

$$
N=2^{n-1}
$$

Denklem 3'te; "n" ASTM tane boyutu numarasını, "N" $100 x$ büyütmede 1 inch $^{2}$ 'deki toplam tane sayısını ifade etmektedir.

Gerçekleştirilen ölçümler ve hesaplamalar neticesinde elde edilen verilere ait ortalama değerler Tablo 15'deki gibidir.

Tablo 15. ASTM tane boyut numaraları ve $100 \mathrm{X}$ büyütmede 1 inch ${ }^{2}$ 'deki toplam tane sayıları

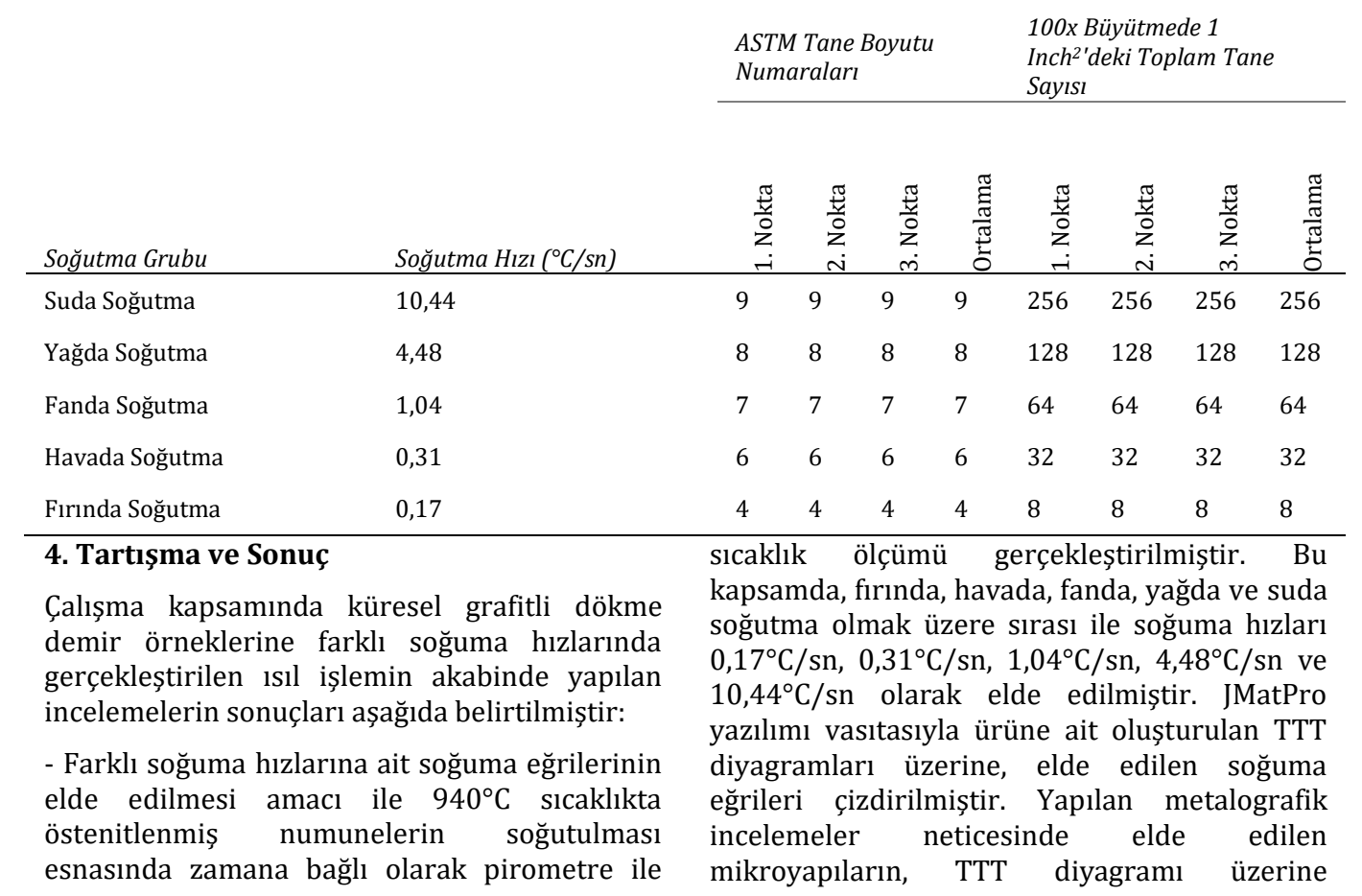


çizdirilen soğuma eğrileri ile uygunluk gösterdiği belirlenmiștir.

- Farklı soğuma hızlarında ölçülen en yüksek sertlik değeri suda soğutulan numunelerde elde edilmiş olup, en düşük sertlik ise furında soğutulan numunelerde ölçülmüștür. $\mathrm{Bu}$ kapsamda artan soğuma hızı ile birlikte sertliğin arttığı tespit edilmiştir. Bu durumun aynı zamanda artan soğuma hızının etkisiyle malzeme iç yapısında beynit fazının oluşum göstermesine bağlı olduğu öngörülmüștür. Aynı zamanda soğuma hızının artması tane boyutunun da küçülmesine neden olmaktadır, böylece artan tane sinırları ile birlikte dislokasyon hareketlerinde zorlanmalar oluşarak tane sınırlarında dislokasyon yığılmalarına neden olur. Bu nedenle sertliğin artmasının yanında mukavemette de artış yaşanmaktadır.

- Metalografik incelemeler sonucunda, soğuma hızının artması ile birlikte iç yapının iğnemsi bir hale dönüștüğü tespit edilmiştir. Fırında soğutulan numunelerin iç yapısı ferrit iken suda soğutulan numunelerin ise beynittir. Bunun yanı sıra, soğuma hızına bağlı olarak tane boyutlarında küçülmeler meydana geldiği tespit edilmiştir.

- Yeșiltepe ve arkadașları tarafından 2017 yılında yapılan çalışmada, küresel grafitli dökme demir örnekleri 1,2 , ve 4 saat olmak üzere farklı tavlama sürelerinde 900 ile $1000^{\circ} \mathrm{C}^{\prime}$ de tavlama işlemine tabi tutulmuştur. Akabinde tüm numune örnekleri su ve havada soğutulmuştur. Tüm numunelerin metalografik incelemeleri gerçekleștirilmiș ve sertlik ölçümleri yapılmıştır. Sonuç olarak mikroyapının, yavaş soğuma şartlarında ferritik, hızlı soğuma șartlarında ise perlitik ve martenzitik olduğu tespit edilmiștir. Buna ek olarak artan soğuma hızı ile sertliğinde arttığı belirlenmiștir [24].

- Yun-Cheng ve arkadașları tarafından 2012 yılında yapılan çalışmada, soğutma hızının karbidik östemperli sünek demirin mikroyapısı ve mekanik özellikleri üzerine etkisi araştırılmıştır. Deneysel sonuçlar, soğutma hızının artmasıyla birlikte, asiküler ferrit boyutunun kademeli olarak ince asiküler ferrit haline geldiğini, ostenit içeriğinin korunduğunu, darbe tokluğunun azaldığını ve numunelerin sertliğinin arttığını göstermektedir [25].
- M.Tartaglia ve arkadașları tarafından 2015 yılında yapılan çalıșmada, sfero dökümde grafit ve metal matris, alaşım içeriği ve gerilme özellikleri arasındaki ilişkileri karakterize ederek daha yüksek bir mukavemet ve süneklik kombinasyonu elde etmenin yollarının belirlenmesi amaçlanmıștır. Bu çalıșmada, ayrıca tane boyutunu iyileştirmek ve bileşimyapı-özellik ilişskilerini optimize etmek için katılaşma sonrası ısıl işlemler araştırılmıştır. Isıl işlem denemeleri, kritik olarak östenitize edilerek ve numunelerin durgun havada soğutma, basınçlı hava ile soğutma ve yağda soğutma gibi çeșitli soğutma hızlarına tabi tutulmasıyla gerçekleștirilmiș, ardından tavlama yapılmıștır. En iyi sonuçlar \%50 ferrit ve $\% 50$ perlitten olușan bir bașlangıç mikro yapısı ile elde edilmiştir. Isıl işlemden sonra, ölçülen mekanik özellikler > 55 ksi akma dayanımı (YS), > 80 ksi maksimum çekme mukavemeti (UTS) ve > \% 12 uzama'dır. Kritik östenitlemeden sonra havayla soğutma veya su verme ve tavlama isıl işlem sonrasında elde edilen mekanik özellikler ise, 65 ila 85 ksi akma mukavemeti, 110 ila 130 ksi maksimum çekme mukavemeti ve \% 8 ila 9 uzama olarak elde edilmiștir [26].

- Kabnure ve arkadașları tarafından 2017 yılında yapılan çalışmada ise, otomobil çark dökümü üzerinde araştırmalar gerçekleștirilmiștir. Küçük kısımların merkezi göbeğe bağlanmayacak bölümlerde kesit kalınlığında değișkenlik olduğundan otomobil çarkı tercih edilmiștir. Döküm uygulamalarının simülasyon analizleri yapılmıştır. Döküm işlemi sonucunda elde edilen numuneler değişken kesit kalınlıkları için mikroyapı ve sertlik bazında incelenmiștir. Belirlenen farklı kesit kalınlığındaki altı kritik bölgede soğutma oranı için yapılan ölçümler sonucunda; kesit kalınlığındaki azalıș ile soğutma hızındaki artışla \% perlitin arttığı ve sertliğin arttığı belirlenmiștir [27].

- Bu çalışmalara istinaden, bu çalışma sonucunda elde edilen sonuçların tutarlılığı tespit edilmiştir.

- Ayrıca soğuma hızının mukavemete olan etkisinin incelenmesi amacı ile sertlik-çekme mukavemeti ilişkisinden yararlanılmıștır. Sertlik-çekme mukavemeti ilișkisini veren grafikten yararlanılarak dökme demirler için bir eğim bulunmuștur. Iki noktası belli olan doğrunun eğimi formülü kullanılarak dökme 
demirler için sertlik-mukavemet dönüsüm formülü elde edilmiștir. Bunun akabinde yapılan sertlik dönüşümü sonucunda elde edilen brinell sertlik değerleri kullanılarak sertlik-mukavemet dönüşümü yapılmış ve farklı soğuma hızlarındaki mukavemet değerleri belirlenmiștir. Yapılan hesaplamalar neticesinde, artan soğuma hızına bağlı olarak mukavemetinde arttığı sonucuna varılmıştır.

- Güzel tarafından 2012 yılında yapılan yüksek lisans tezinde, Șekil 19'da verilen küresel grafitli dökme demirlerin sertlik ve dayanımı arasındaki ilişkiyi gösteren grafikte, artan sertlik sonucunda çekme mukavemetininde arttığı görülmektedir [23].

Bu kapsamda, bu çalıșmada formüle dayalı olarak hesaplanan çekme dayanımı değerlerinin, artan sertlik ile artacağı tespit edilmiş olup, Güzel'in tezinde yer alan grafik ile kıyaslandığında, bu çalışma sonucunda elde edilen sonuçların doğru olabileceği öngörülebilir.

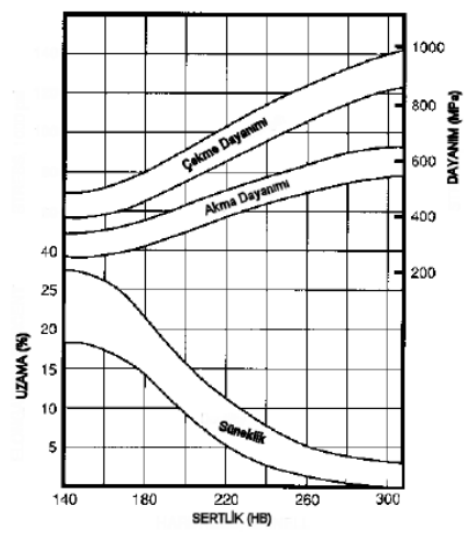

Şekil 19. Küresel grafitli dökme demirlerde sertlik ve dayanım arasındaki ilișki [23]

- Ayrıca JMatPro yazılımı ile yapılacak olan farklı bir ısıl ișlem șartının doğruluk payının yüksek olacağ geliştirilebilecek kimyasal kompozisyonlara göre farklı ısıl ișlem parametrelerinin optimize edilebileceği açıtırır.

\section{Teșekkür}

Projedeki deney çalıșmalarının gerçekleștirilebilmesi için laboratuvar olanaklarını kullanımımıza açan Kocaer Celik Sanayi ve Ticaret A.Ş.'ye teşekkürü bir borç biliriz. Bu vesile ile tüm Kocaer Ar-Ge Merkezi personeline projemize verdikleri destek için de ayrıca teșekkür ederiz.

\section{Kaynakça}

[1] Stefanescu, D.M., 1990. Classification and Basic Metallurgy of Cast Iron, ASM Handbook, Cilt. 1. DOI: 10.1361/asmhba0001001

[2] Aran, A., 1991. Lamel ve Küresel Grafitli Dökme Demirlerin Issl Işlemleri. https :// web.itu.edu.tr/ arana/dd.pdf (Erișim Tarihi: 10.06.2020)

[3] Karsay, I.S. 1990. Ductile iron-production practies. American Foundrymen's Society Inc., USA, 188s.

[4] Sen, U. 1997. Küresel Grafitli Dökme Demirlerin Bor Kaplanması ve Kaplama Özellikleri. İstanbul Teknik Üniversitesi, Fen Bilimleri Enstitüsü, Doktora Tezi, $177 \mathrm{~s}$, İstanbul

[5] ASM Metals Handbook, 1990. Properties and selection: irons, steels and high performance alloys, Vol.1. Tenth Edition, ASM International.

[6] Budinski, K.G, Budinski, M.K. 2010. Engineering Materials: Properties and Selection. Prentice Hall, Upper Saddle River, N.J.490

[7] Çelik, Ö. 2001. Küresel Grafitli Dökme Demirlerin Aşınma Davranışları. İstanbul Teknik Üniversitesi, Fen Bilimleri Enstitüsü, Yüksek Lisans Tezi, 115s, İstanbul.

[8] Akman, C. 2006. GG 22 Lamel Grafitli Dökme Demirden Üretilen Motor Silindir Gömleklerinin CNC Torna Tezgahında İșlenebilirliğinin İncelenmesi. Balkesir Üniversitesi, Fen Bilimleri Enstitüsü, Yüksek Lisans Tezi, 119s, Balıkesir.

[9] Söğüt, A. 1998. Küresel Grafitli Dökme Demirde Küreleşme Oranının Mekanik Etkisinin İncelenmesi. Gazi Üniversitesi, Fen Bilimleri Enstitüsü, Yüksek Lisans Tezi, 111s, Ankara.

[10] Larker, R. 2009. Solution Strengthened Ferritic Ductile Iron ISO 1083/IS/500-10 Provides Superior Consistent Properties In Hydraulic Rotators, China Foundry, Cilt. 6, s. 343-351.

[11] Toptas, M. 2009. Farklı Isl İșlemlerin Küresel Grafitli Dökme Demirin Yorulma Davranışına Etkisi, Afyon Kocatepe Üniversitesi, Fen Bilimleri Enstitüsü, Yüksek Lisans Tezi, 85s, Afyonkarahisar.

[12] Döngel, A. 2008. Bortemperlenmiş Küresel Grafitli Dökme Demirin Yüksek Sicaklı Așınma Davranıșının İncelenmesi. Afyon Kocatepe Üniversitesi, Fen Bilimleri Enstitüsü, Yüksek Lisans Tezi, 96s, Afyonkarahisar.

[13] Celik, O. N. 1996. Küresel Grafitli Dökme Demirlerde $\mathrm{Cu}, \mathrm{Ni}$ ve Mo Alaşım Elementlerinin Östemperleme Sonucu Beynit Oluşumuna Etkisinin İncelenmesi ve Sinirsel Ağ Modeli İle Değerlendirilmesi. Osmangazi Üniversitesi, Fen Bilimleri Enstitüsü, Doktora Tezi, 129s, Eskișehir.

[14] Ayday, A. 2013. Elektrolitik Plazma Teknolojisi İle Küresel Grafitli Dökme Demir Malzemesinin Yüzey Özelliklerinin Geliștirilmesi. Sakarya Üniversitesi, Fen Bilimleri Enstitüsü, Doktora Tezi, 218s, Sakarya.

[15] Çavuşoğlu, E. 1992. Döküm Teknolojisi I. Döküm Yöntemleri-Dökme Demirler. Ofset Atölyesi, İstanbul, 289-299s.

[16] Yılmaz, F. 2003. İçme-Atık Su Ve Gaz Dağtım Şebekelerinde Dökme Demirler ve Düktil Demir Uygulamaları. İstanbul Büyükșehir Belediyesi Su ve Kanalizasyon İdaresi Yayınları, İstanbul, 240s.

[17] Elliot, R.1988. Cast iron Technology. Butterworths \& Co Ltd., London, $247 \mathrm{~s}$. 


\section{DEÜ FMD 23(69), 1033-1048, 2021}

[18] Koç, Ș. 2008. Küresel Grafitli Dökme Demirlerde GGG50 Mekanik Özelliklerinin Isı Ișlem Ile Sağlanması, TMMOB Metalurji Mühendisleri Odas Metalurji Dergisi, Cilt. 151, s. 20-27.

[19] Karaman S. 2011. Küresel Grafitli Dökme Demirlerin (GGG40, GGG50, GGG60, GGG70) Üretim Sürecinin Ve Mekanik Özelliklerinin İncelenmesi. Trakya Üniversitesi, Fen Bilimleri Enstitüsü, Yüksek Lisans Tezi, 116s, Edirne.

[20] Topbaș, M. A. 1993. Isıl ișlemler. Prestij Basın, İstanbul, 199s.

[21] Callister, D. W. 2007. Materials Science and Engineering; an introduction. John Wiley \& Sons, Inc. USA, 975s

22] Hasırcl, H. 2000. Östemperlenmiş Küresel Grafitl Dökme Demirlerde Alașım Elementlerinin ( $\mathrm{Cu} \mathrm{Ve}$ $\mathrm{Ni}$ ) Ve Östemperleme Süresinin Mikroyapı Ve Mekanik Özellikler Üzerine Etkisi. Gazi Üniversitesi, Fen Bilimleri Enstitüsü, Yüksek Lisans Tezi, 92s, Ankara.

[23] Güzel, E. 2012. Rüzgar Türbini Dökümlerinde Hassas Metalürjik Değişkenlerin Optimizasyonu.
Yıldız Teknik Üniversitesi, Fen Bilimler Enstitüsü, Yüksek Lisans Tezi, 164s, İstanbul.

[24] Yeşiltepe S., Şeşen M.K. 2017. Heat treatment effect on spheroidal graphite, microstructure and mechanical properties of Ni-resist ductile cast iron. Mühendislik Bilimleri ve Tasarım Dergisi, Cilt 5, s. 479 - 482.

[25] Yun-Cheng, P., Hui-Jin, J., Jin-Hai, L., Guo-Lu, L. 2012. Influence of cooling rate on the microstructure and properties of a new wear resistant carbidic austempered ductile iron (CADI), Materials Characterization, Cilt 72, s. 53-58.

[26] M.Tartaglia, J., B.Gundlach, R., M.Goodrich., G. 2015. Optimizing Structure-Property Relationships in Ductile Iron, International Journal of Metalcasting. Cilt 8, s. 7-38.

[27] Kabnure, B.B., Shinde V.D., Kolhapure R.R. 2017. Property Optimization of Impeller Casting Using GRA. International Conference on Advances in Thermal Systems, Materials and Design Engineering (ATSMDE 2017), 21-22 Aralık, Hindistan, 1-7. 